\title{
Misguided policy may jeopardize a diverse South brazilian environmental protection area
}

\author{
Gustavo Henrique Zaia Alves ${ }^{1 *}{ }^{-}$, Regiane da Silva Santos ${ }^{I}$, Bruno R. S. Figueiredo ${ }^{I}$, \\ Gislaine Iachstel Manetta', Hugo José Message ${ }^{2}$, Laryssa H. R. Pazianoto', Gilson Burigo Guimarães ${ }^{3}$, \\ Evanilde Benedito ${ }^{1}$ \& Edivando Vitor do Couto ${ }^{4}$ \\ ${ }^{1}$ Universidade Estadual de Maringá, Av. Colombo, 87020-900, Maringá, PR, Brasil \\ ${ }^{2}$ Universidade Estadual do Oeste do Paraná, Campus de Toledo, Jd. La Salle, 645, Toledo, PR, Brasil \\ ${ }^{3}$ Universidade Estadual de Ponta Grossa, Ponta Grossa, PR, Brasil \\ ${ }^{4}$ Universidade Tecnologica Federal do Paraná, Campo Mourão, PR, Brasil \\ *Corresponding author: Gustavo Henrique Zaia Alves, e-mail: alvesghz@yahoo.com.br
}

\begin{abstract}
ALVES, G. H. Z., SANTOS, R. S., FIGUEIREDO, B. R. S., MANETTA, G. I., MESSAGE, H. J., PAZIANOTO, L. H. R., GUIMARÃES, G. B., BENEDITO, B., COUTO, E. V. Misguided policy may jeopardize a diverse South brazilian environmental protection area. Biota Neotropica. 19(1): e20180574. http://dx.doi.org/ 10.1590/16760611-BN-2018-0574
\end{abstract}

\begin{abstract}
The Devonian Escarpment (DEEPA), located in the south of Brazil, represents an important area of environmental preservation composed by grasslands, gallery forests, as well as rock outcrops and archaeological sites. A law project (LP 527/2016), which suggests a reduction of the DEEPA area in approximately $70 \%$ of its original area (from 393,579 to 125,895 ha), is currently being processed in the Paraná State House of Representatives. Such reduction seems to be related to economic interests (mainly agriculture and mining) in the state of Paraná. If approved, LP 527/2016 will allow farmers to deliberately expand their activities, with the suppression of natural forest as main consequence. Additionally, loss of faunal diversity, contamination of water and soils, and alteration in nutrient cycles are expected, due the intensive use of agrochemicals. In addition to the direct environmental consequences, we expect the disappearance of areas of high geological interest, reducing local geodiversity, as well as substantial economic losses with ecotourism. Brazil is a signatory to the United Nations Convention on Biological Diversity, where it undertakes to develop strategies to prevent biodiversity loss and ecosystem degradation by 2020. An approval of the LP would be contradictory, considering that there are few natural vegetation areas in this region of the country. We emphasize that the proposal of such projects goes against the sustainability in the country and disregard the scientific knowledge generated until then. Thus, it is necessary to develop regional and federal political objectives that guarantee economic development in a balanced way, considering the local bio and geodiversity, not the proposal of mechanisms that destroy them.
\end{abstract}

Keywords: Environmental law, Grassland, Devonian Escarpment, Biodiversity loss, Geodiversity.

\section{Política equivocada pode colocar em risco uma área de preservação ambiental do sul do Brasil}

\footnotetext{
Resumo: A Escarpa Devoniana (APAED), localizada no sul do Brasil, representa uma importante área de preservação ambiental composta por campos, matas de galeria, além de afloramentos rochosos e sítios arqueológicos. Atualmente, tramita na câmara dos deputados do estado do Paraná um projeto de lei estadual (PL 527/2016) que sugere a redução da área da APAED em aproximadamente 70\% de sua área original (de 393.579 para 125.895 ha). Tal redução parece estar relacionada com interesses econômicos (principalmente agropecuária e mineração) no estado do Paraná. Caso aprovado, o PL 527/2016 permitirá que agricultores expandam suas atividades deliberadamente, tendo como consequência principal a supressão de áreas de floresta nativa. Com isso, espera-se perda de diversidade faunística, contaminação de água e solos e alteração nos ciclos de nutrientes, dado o aumento no uso de agroquímicos. Além das consequências ambientas diretas, podemos esperar o desaparecimento de elevado interesse geológico, reduzindo a geodiversidade local, além de substanciais perdas econômicas com ecoturismo. O Brasil é um dos países signatários
} 
da Convenção da Diversidade Biológica das Nações Unidas, onde se compromete a desenvolver estratégias que evitem a perda da biodiversidade e a degradação de ecossistemas até 2020. Assim, a aprovação desse projeto de lei é, no mínimo, contraditória considerando que existem poucas áreas de vegetação natural nessa região do país. Destacamos que a proposta de tais projetos vai contra a sustentabilidade no país e desconsideram o conhecimento científico gerado até então. Dessa forma, é necessário o desenvolvimento de objetivos políticos regionais e federais que garantam o desenvolvimento econômico de forma equilibrada, considerando a bio e geodiversidade local, e não a proposta de mecanismos que as destruam.

Palavras-chave: Lei ambiental, Campos Gerais, Escarpa Devoniana, Perda da biodiversidade, Geodiversidade.

\section{Introduction}

Protected areas are proposed to preserve and protect the biodiversity and its components, such as habitats, species, populations, and ecosystem services (Margulis \& Pressey 2000), and their effectiveness has been widely shown (e.g. Frederico et al. 2018). In Brazil, the protection of natural areas is guaranteed by the National System of Conservation Units of Nature (SNUC in Portuguese - federal law 9.985/2000), whose main objectives are, among others, to protect endangered species, and preserve and recover the diversity of natural ecosystems. However, Brazilian natural resources have repeatedly been targeted with misguided policies (Bernard et al. 2014, Azevedo-Santos et al. 2015, Tófoli et al. 2016, Azevedo-Santos et al. 2017, Tófoli et al. 2017, Alves et al. 2018, Silveira et al. 2018). Currently, more than 20 legislative proposals are circulating in the Brazilian Congress to loosen regulations governing activities such as building roads and hydroelectric dams or expanding agricultural businesses (Tollefson 2016, Ferrante \& Fearnside 2018). For example, the constitutional amendment 65/2012 (i.e. PEC 65/2012) has been proposed with the aim to weaken the licensing process of large developments by loosening the current power that environmental agencies have to suspend a project based on its Environmental Impact Assessment (EIA). As a consequence, EIA would no longer be necessary and mitigation and compensation, now required and supervised by the licensing authority, would be voluntary (El Bizri et al. 2016).

Other political proposals intend to reduce the size and/or the protected status from conservation units in specific regions of Brazil. According to SNUC, there are two main categories of conservation units: Integral Protection Units (IPU - a restricted category in terms of use of natural resource) and Sustainable Use Units (SUU), whose main objective is to reconcile the conservation of nature with the sustainable use of a portion of its natural resources. Last year, a law project (LP 8107/2017) was edited by the Brazilian National Congress aiming to alter the conservation status of the Jamanxim National Forest (i.e. a subcategory of IPU) in Pará state. According to this LP (which is still being processed in the House of Representatives), about $27 \%$ of the area of this national forest will be transformed in Environment Protection Area (EPA), a subcategory of SUU which allows the anthropic occupation and sustainable exploitation of natural resources. If approved, an area of approximately 350,000 ha of the Amazonian forest will be less protected and more likely to be deforested. The main argument for this action is to regularize illegal occupations that are already transforming the forest into a pasture and/or cropland.

Another recent nationwide law project (LP 3.751/2015) aims to revoke the legal status of the recently established IPU for which land ownership conflicts are not resolved within 5 years of PA creation.
According to Silveira et al. (2018), if this law goes further, all future and current protected areas will be affected, including those located in the Amazon and in the two Brazilian hotspots for biodiversity: Atlantic Forest and Cerrado (Myers 2000). Clearly, those policies have a bias towards production and economy-driven activities.

The strategy for "boosting the economy" at the cost of loosening environmental protection is not restricted only to federal regulations; municipalities and states also play a big role on these actions (i.e. Azevedo-Santos et al. 2015, Tófoli et al. 2016, Alves et al. 2018). Currently, there is one regional law project, in Paraná State (South Brazil), that intends to reduce an environmental protection area (the Devonian Escarpment EPA) by legal means that are environmentally hostile. This project will reduce the degree of protection in one conservation unit, with the intention of favoring agriculture, such as crop and livestock production.

\section{Overview of the Devonian Escarpment EPA}

The Devonian Escarpment EPA (hereafter DEEPA) was created in 1992 under a state decree (Paraná state decree no. 1231/1992) whose primary objective was to protect the bio- and geodiversity of a natural area of approximately 393.579 ha, with a unique set of vegetation with high rates of biodiversity and endemism. This area is mainly composed by grasslands, gallery woods, rocky outcrops, and canyons and patches of Araucaria forest (a forest dominated by the gymnosperm Araucaria angustifolia, a species endangered of extinction; Maack 1948, Paraná 2004, Thomas 2013). This EPA is a crucial area for biodiversity preservation because it comprises within its limits four State Parks, five Private Reserve of Natural Heritage, a significant portion of the Campos Gerais National Park, and integrates important Brazilian river basins (such as the Paranapanema and Paraná Rivers) through a river network composed by the Tibagi, Iguaçu and Ribeira Rivers (Paraná 2004, Oliveira 2014). Furthermore, it is situated at the limit of two biomes: the Atlantic Forest and the Cerrado (i.e. Brazilian Savannah). Both biomes have high rates of aquatic and terrestrial biodiversity, but also are amongst the most threatened habitat in the planet. The landscapes of those biomes are highly fragmented and have been considered hotspot for biodiversity conservation, since they support many endemic and threatened species (Myers 2000, Conte et al. 2016, Paulitsch 2017).

The geodiversity of the DEEPA is an expression of a vast assemblage of products and processes related to the geological contrast between the Paraná Basin and its basement rocks, notably the Devonian sandstones of the Furnas Formation. Stones from this lithostratigraphic unit support the topographic step known as the "Devonian Escarpment", reaching altitudes as high as 1,290 m. Geological (mineralogy of sandstones and tectonic structures), geomorphological and hydrological factors 
led to an expressive hydrographic network, but also to a peculiar karst system in non-carbonate rocks. The geodiversity of the DEEPA hosts the principal regional aquifer and unique ecological conditions with newly discovered species, including troglobiont organisms (Cardoso et al. 2014). The regional geodiversity framework is complemented with a large variety of soils that sustain the typical grassland landscape, its agricultural use and regional identity (Melo et al. 2007, Guimarães et al. 2009, Melo et al. 2011, Guimarães et al. 2017).

Although extremely important for geo- and biodiversity conservation, this area has already been jeopardized by many anthropogenic pressures since its creation, such as cattle livestock, mining exploration and reforestation with exotic tree species, but mainly by agricultural practices developed in the region. The DEEPA is included in an area that is known to be the largest producer of grains in the Paraná state (SEAB 2015). In fact, the state of Paraná currently is the $2^{\text {nd }}$ larger producer of soybean in Brazil, and its crop areas are exponentially increasing since 1970 , reaching approximately 5,000,000 ha of planted area in 2015, with the potential to increase in next years (SEAB 2015). Because of this exacerbating production, the removal of native vegetation and replacement by corn and soybean crops is constant (SEAB 2015). Only 3\% of the original Araucaria forest remains, and its deforestation is continuously increasing (e.g. between 2014 and 2015, 1,777 ha of this region was deforested, representing approximately $89 \%$ of all deforestation in Paraná) (SOS Mata Atlântica 2013). This habitat fragmentation has effects on the regional fauna, which depends directly on these areas as a refuge, places for breeding, foraging (Cleary et al. 2016, Jeliazkov et al. 2016) and pollination (Solé-Senan et al. 2017).

Intensification of agriculture has been pointed out as one of the greatest causes of biodiversity loss in agroforestry systems, mainly in developing countries where the access to advanced methods and technology are limited (Pereira et al. 2012, Tilman et al. 2017, Djagba et al. 2018). The effects of this anthropogenic impact are acknowledged to be twice as many harmful to biodiversity in tropical ecosystems (Barlow et al. 2016) and are noticeable in all organization levels (i.e. from microorganisms to ecosystems services; Storkey et al., 2013, Solé-Senan et al. 2017). Additionally, we can expect soil quality degradation and water contamination due to the use of fertilizers and pesticides. (Reynolds et al. 2015, Djagba et al. 2018). In the DEEPA region, for example, besides the suppression of native vegetation, the agriculture intensification may also contribute with the contamination of water bodies by agrochemicals, which has been reported to cause mass death of aquatic organisms and affect water quality and supply to its surrounding municipalities (Ayres 2006, Oliveira 2014).

\section{Unsustainable Policy}

The DEEPA is already struggling to overcome all the above mentioned anthropogenic impacts, and policymakers are insisting on putting this vital environment at serious risk again. Currently, an unsustainable law project (LP 527/2016) is being proposed for the DEEPA, which plans to reduce the area of this protection area by $70 \%$ (Figure 1). The LP claims the federal law 9.985/2000, which guarantees the sustainable use of the environment, to justify the resizing of the protection area. However, article no. 225 of the Brazilian Federal Constitution prohibits the use of an area, even for sustainable use, if its protection is not guaranteed. It seems evident that the term "sustainability" has been intentionally misinterpreted for economic benefits.

The 527/2016 LP aims to reduce de DEEPA area from 393,579 ha to 125,895 ha (Figure 1). Its central argument is the technical limitation of the original State decree to precisely delimit the protection area boundaries. However, the new proposal is anchored in the following criteria: the landowner would have to keep its area as an EPA only if the areas of rocks outcrops and natural forests exceed the areas of production (i.e. if the natural area comprises more than $50 \%$ of the property). Otherwise, the landowner would be allowed to use its area deliberately, such as suppress natural vegetation of the remaining area to increase its productive area. Therefore, such areas destroyed by years of inadequate use would be ignored (rather than recovered), and the remaining preserved areas could be reduced by up to $50 \%$.

Furthermore, the new proposal completely ignores the endangered gymnosperm Araucaria angustifolia, treats the grasslands as 'consolidated' areas by agriculture activities, and the rich fauna that inhabits the DEEPA is completely unconsidered. The original DEEPA Management Plan recorded 92 mammals, 337 birds, 60 reptiles, 51 amphibians, and 92 fish species, representing 63\%, 47\%, 39\%, 40\%, and $15 \%$ of the Paraná state' species, respectively. Since this area is poorly studied, its species richness should be much higher. Moreover, the resized DEEPA's map excludes a series of outstanding geosites, with representatives of the geoheritage of the Campos Gerais region, and also archaeological points of interest, mainly with thousand years art rock and settlements. It also worth to mention that in the DEEPA's region there are two of the most visited parks of Paraná state (i.e. Vila Velha State Park and Guartelá State Park). Those parks are important to the economy of the region because they contribute significantly to the increase in revenues generated by ecotourism in the southern region of Brazil (SETU 2012, PRTUR 2014).

\section{Landscape Consequences of the Law Project Approval}

Currently, there are 25,707 fragments remnants of the Atlantic forest and Cerrado forest with its area ranging from 0.08 ha to $11,779,18$ ha, and 1,423 remnants of the Grasslands ranging from 0.08 ha to 50 ha in the original area of the DEEPA. The forest fragments accounted for $23 \%$, and Grasslands $0.04 \%$ of the total area of the DEEPA (Figure 2 and Table 1).

Grassland areas (i.e. Campos Gerais) are critically in danger of disappearing within the DEEPA. Currently, they represent only $0.04 \%$ of the total DEEPA's area, with a size always smaller than 50 ha. This means that grasslands, which are usually neglected in conservation plans (Overbeck et al. 2015), are losing area to planted pasture, agriculture and forest plantations (see Table 1). The grasslands, in its various physiognomies, have been under severe pressure with the expansion of agricultural, livestock and silvicultural activities. At the same time, due to their great scenic beauty, some regions of the Campos Gerais are highly sought for tourism and recreational purposes. The current conservation status of grasslands in Paraná state also results from historical processes of use and occupation of the soil, being related to the agricultural expansion since the cycle of the first colonizers this region. The remnants of native grasslands are mostly in areas of rugged terrain, which are not amenable to agricultural mechanization, and the 

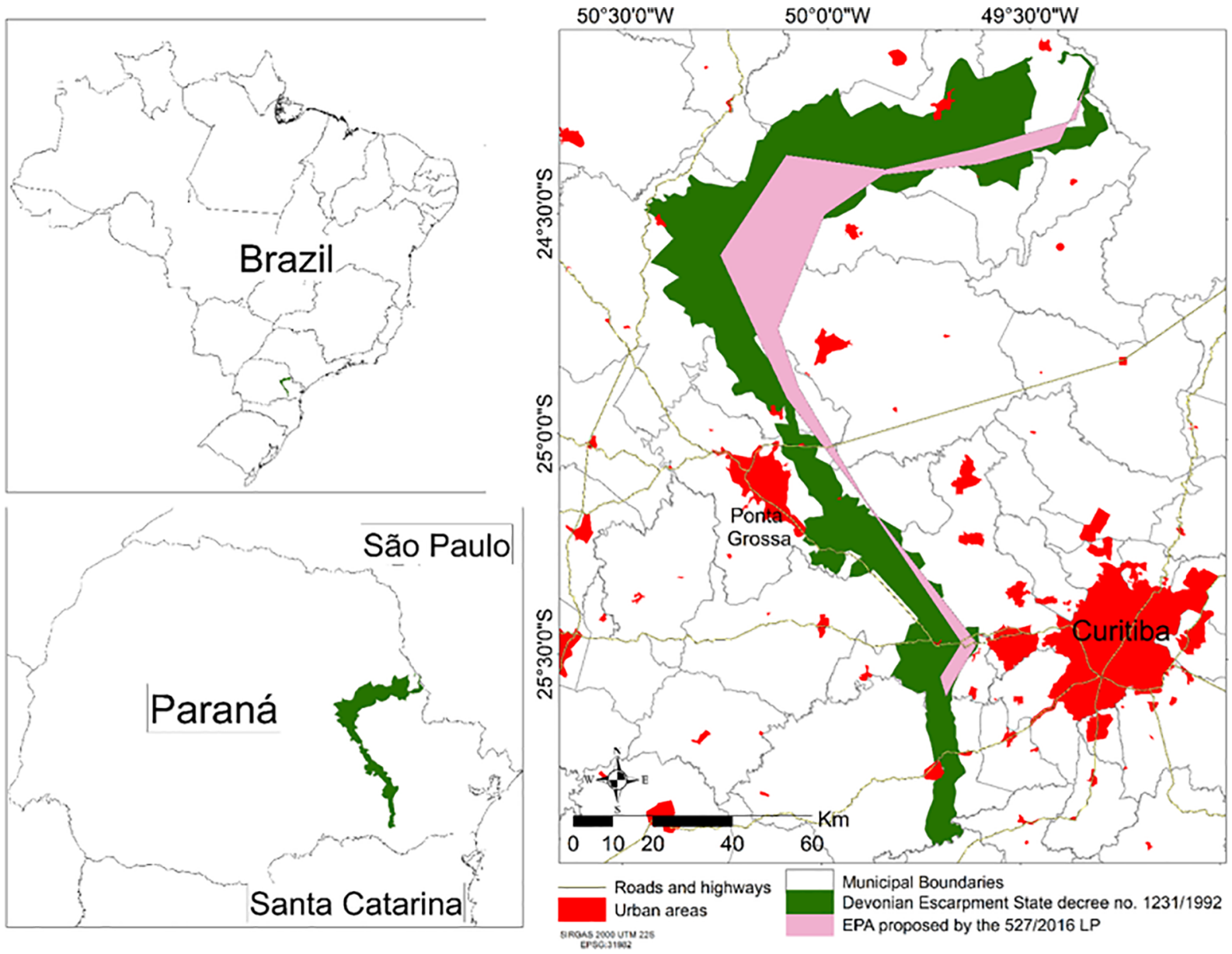

Figure 1. The original area of the DEEPA (in green) and the resized DEEPA proposed by the 527/2016 LP (in pink) in Paraná State, South Brazil.

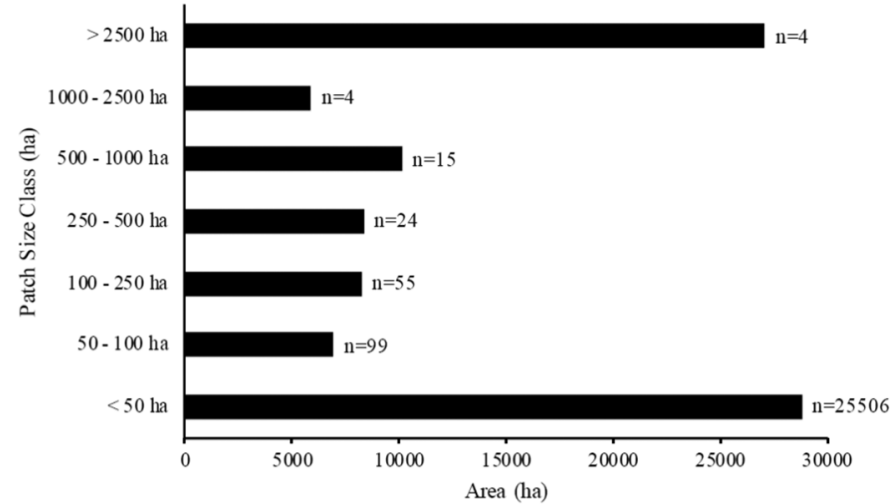

Figure 2. Distribution of the fragments remnants of the Atlantic forest and Cerrado (Brazilian Savannah) areas in the DEEPA. Based on the available data of fragments database from MapBiomas 2.3 (Available at: http://mapbiomas.org).

less fragmented portions are found within the state (e.g. Vila Velha and Guartelá State Parks) and federal Conservation Units (e.g. Campos Gerais National Park) (Dalazoana \& Moro, 2011).

Most of the remaining fragments in the DEEPA are small patches (patches $<50$ ha accounts for $99.2 \%$ of all forest fragments; Figure 2). The area of a patch is closely linked to its ability to accommodate greater species diversity since larger areas can offer better conditions for
Table 1. Area occupied and percentage (\%) by land cover classes inside the current area of the DEEPA. Based on the available data of fragments database from MapBiomas 2.3 (Available at: http://mapbiomas.org). Categories are based on MapBiomas 2.3. Forest Formations $=$ represents Atlantic forest and Cerrado patches; Forest Plantation $=$ forestry patches; Grassland $=$ natural grasslands .

\begin{tabular}{lcc}
\hline Class & Area (ha) & \% \\
\hline Forest Formations & $95,392.62$ & 23.0 \\
Forest Plantation & $51,182.43$ & 12.3 \\
Grasslands & 201.41 & 0.04 \\
Pasture & $67,641.6$ & 16.3 \\
Agriculture & $197,782.6$ & 47.6 \\
Non-vegeted areas & 98.41 & 0.02 \\
Urban Infrastructure & $15,53.31$ & 0.37 \\
Water bodies & 886.94 & 0.21 \\
\hline
\end{tabular}

species-habitat interactions, consequently promoting the establishment of viable populations of local species (Metzger et al. 2009). With the expected reduction of the DEEPA, Atlantic forest, Cerrado savannas and grasslands patches will likely be reduced and/or eliminated from the landscape. The smaller patches can be negatively influenced by species-habitat interactions, resulting in local biodiversity loss (Fahrig 2003). This decrease in biological diversity is linked to ecological 
changes such as the imbalance of the higher rate of species extinction and the lower immigration rate of species from the neighboring fragments (Kageyama et al. 1998, Laurance \& Vasconceloz 2009).

Suppressing small patches brings even more significant damage to biodiversity. The presence of small fragments is an important starting point for reducing the spatial isolation of the existing large fragments (e.g. Ribeiro et al. 2009, Ferreira et al. 2014, Ferreira et al. 2018, comparing isolation indices of fragments larger or smaller than 50 ha in all the Atlantic Forest remnants). Additionally, small fragments have ecological benefits to the landscape because they can act as steppingstones for species movements, increasing the connectivity among larger fragments. Also, small fragments increase the genetic flow through the surrounding matrix and promote the patch colonization process, the efficiency of these small fragments as steppingstones are related to the permeability of the matrix (Baum et al. 2004). The more suitable the matrix, the more support it offers to species that move among the patches (Gascon et al. 1999, Murphy \& Lovett-Doust 2004).

The reduction of this critical environmental protection area will put at risk the remaining forest fragments and grasslands that preserve the geodiversity and the endemic biodiversity of the region. The DEEPA currently has a regulatory function that controls the different types of land use. The rural properties included inside the DEEPA has to keep a Permanent Preservation Area (PPA) of the forest as a function of the river width (i.e. the wider the river, the larger the PPA of riparian vegetation). With the reduction of this EPA and exclusion of rural properties of the EPA category, the area outside the ranges of the new protection area proposed by the LP will be regulated by the recently modified Brazilian Native Vegetation Protection Law (law 12651/2012), whose effects for preserving biodiversity were widely criticized by environmentalist and the scientific community (e.g. Bernard et al. 2014, Soares-Filho et al. 2014 and Vieira et al. 2018).

According to the Brazilian Native Vegetation Protection Law (BNVPL), the Permanent Preservation Area of rural property is a function of the size of the area and not of the river width (as it is in the EPA category), which disrupt the function of ecological corridors provided by PPAs included in the EPA category. For example, a large rural property could have a PPA of $30 \mathrm{~m}$ and the neighboring property, if smaller, could have a PPA of $5 \mathrm{~m}$; in this scenario, many ecological functions would be disrupted such as the ecological corridors, the availability of shelter for animals and, also, the genetic flow among populations. Moreover, the BNVPL authorize that the PPAs, which were being used for agriculture, livestock or any economic use, to maintain its activities without having to restore it. Also, it does not mention the restoration of escarpments, mountains and other high elevation and slope places, which is a threat to the geodiversity of the DEEPA. Elevations areas preserve landforms sustained by geologic formations that resisted to denudation, climatic changes and tectonic forces for many geological eras, and, therefore, conserve important fossils that preserve the evolutionary history of the South American Plate.

\section{Concluding Remarks}

Despite all these alerts, it would not be the first time that the Brazilian government ignores scientific knowledge. The freeze of the public spending on nature protection for the next 20 years, as mentioned by Magalhães (2017), will lead to irreversible damage to what is still left of the Campos Gerais region. If approved, the LP $527 / 2016$ will transform the DEEPA at current sustainable use into an unsustainable non-regulated area, allowing farmers to expand their croplands deliberately. The United Nations declared the current decade the 'Decade of Biodiversity' (Tscharntke et al. 2012), and the Convention on Biological Diversity (CBD) set targets (Aichi targets) to prevent biodiversity loss and degradation of ecosystems until 2020. Brazil is one of the signatory countries and committed to achieving all Aichi targets, including the target no. 11, which aims to conserve, at least, $17 \%$ of terrestrial areas of particular importance for biodiversity. Currently, the Atlantic Forest (which includes the DEEPA) has less than $10 \%$ of its area preserved through conservation units (MMA 2017). The approval of the LP 527/2016 will reduce the length of the protection area instead of increasing it, which is contradictory to the CBD international agreement that Brazil committed to taking part in. While South American and European countries are going towards conservation and creation of new preservation areas (e.g. Spain is removing dams from rivers to restore its ecosystems, and Chile is amplifying its national parks in the Patagonia region; Schiermeier 2018; La Nación 2017), Brazil is going on the opposite direction. Ultimately, a key challenge is to develop regional and federal political goals that ensure the biodiversity conservation, not to destroy it.

\section{Author Contributions}

Gustavo Henrique Zaia Alves: Conceptualized the idea and wrote main manuscript.

Regiane da Silva Santos: Contributed with the research about the overview of the Devonian Escarpment and critical revision adding intellectual content.

Bruno R. S. Figueiredo: Contributed equally to manuscript preparation; contribution to critical revision by adding intellectual content.

Gislaine Iachstel Manetta: Contributed equally to manuscript preparation; contribution to critical revision by adding intellectual content.

Hugo José Message: Contributed equally to manuscript preparation; contribution to critical revision by adding intellectual content.

Laryssa H. R. Pazianoto: Contributed equally to manuscript preparation; contribution to critical revision by adding intellectual content.

Evanilde Benedito: Contributed equally to manuscript preparation; contribution to critical revision by adding intellectual content.

Gilson Burigo Guimarães: Contributed to critical revision by adding intellectual content in regard to geological aspects and geodiversity.

Edivando Vitor do Couto: Build the map and ran the landscape analysis in MapBiomas 2.0; also, contributed to critical revision by adding intellectual content.

\section{Conflicts of interest}

The authors declare that they have no conflict of interest related to the publication of this manuscript. 


\section{References}

ALVES, G.H.Z., TÓFOLI, R.M., MESSAGE, H.J., LIMA-JÚNIOR, D.P. \& HOEINGHAUS, D.J. 2018. New decree promotes fish invasion in Amazon and Pantanal. Biodivers. Conserv. Doi: https://doi.org/10.1007/ s10531-018-1533-y.

AYRES, O.M. 2006. Os animais dos Campos Gerais (PR): impactos ambientais noticiados pela imprensa regional. Publicatio UEPG: Ciências Biológicas e da Saúde. 12:7-19.

AZEVEDO-SANTOS, V.M., FEARNSIDE, P.M., OLIVEIRA, C.S., PADIAL, A.A., PELICICE, F.M., JR. LIMA, D.P., SIMBERLOFF, D., LOVEJOY, T.E., MAGALHÃES, A.L.B. ORSI, M.L. AGOSTINHO A. A., ESTEVES, F.A. POMPEU, P.S. LAURANCE, W.F.M. PETRERE JR, MORMUL, R.P. \& VITULE, J. R.S. 2017. Removing the abyss between conservation science and policy decisions in Brazil. Biodivers. Conserv. 26:1745-1752.

AZEVEDO-SANTOS, V.M., PELICICE, F.M., LIMA-JUNIOR, D.P., MAGALHÃES, A.L.B., ORSI , M.L., VITULE, J.R.S. \& AGOSTINHO, A.A. 2015. How to avoid fish introductions in Brazil: education and information as alternatives. Braz. J Nat. Conserv. 13:123-132.

BARLOW, J., LENNOX, G.D., FERREIRA, J., BERENGUER, E., LEES, A.C., NALLY, R.M.,. THOMSON, J.R., FERRAZ, S.F.B, LOUZADA, J., OLIVEIRA, V.H.F., PARRY, L., SOLAR, R.R.C., VIEIRA, I.C.G., ARAGÃO, L.E.O.C., BEGOTTI, R.A., BRAGA, R.F., CARDOSO, T.M., OLIVEIRA JR, R.C., SOUZA JR, C.M., MOURA, N.G., NUNES, S.S., SIQUEIRA, J.V., PARDINI, R., SILVEIRA, J.M., VAZ-DE-MELLO, F.Z., VEIGA, R.C.S., VENTURIERI, A. \& GARDNER, T.A. 2016. Anthropogenic disturbance in tropical forests can double biodiversity loss from deforestation. Nature. 535:144-147.

BAUM, K.A., HAYNES, K.J., DILLEMUTH, F.P. \& CRONIN, J.T. 2004. The matrix enhances the effectiveness of corridors and stepping stones Ecology. 85:2671-2676.

BERNARD, E., PENNA, L.A.O. \& ARAÚJO E. 2014. Downgrading, downsizing, degazettement, and reclassification of protected areas in Brazil. Cons. Biol. 28:939-950.

CARDOSO, G.M., ARAUJO, P.B., BUENO, A. A.D.E.P. \& FERREIRA, R. L., 2014. Two new subterranean species of Hyalella Smith, 1874 (Crustacea: Amphipoda: Hyalellidae) from Brazil. Zootaxa. 3814:353-368.

CLEARY, K.A., WAITS, L.P. \& FINEGAN, B. 2016. Agricultural intensification alters bat assemblage composition and abundance in a dynamic Neotropical landscape. Biotropica. 48:667-676.

CONTE, C.E., ARAUJO-VIEIRA, K., CRIVELLARI L.B. \& BERNECK, B.V.M. 2016. A new species of Scinax wagler (Anura: Hylidae) from Paraná, Southern Brazil. Zootaxa. 419:245-265.

DJAGBA, J.F., ZWART, S.J., HOUSSOU, C.S., TENTÉ, B.H.A. \& KIEPE, P., 2018. Ecological sustainability and environmental risks of agricultural intensification in inland valleys in Benin. Environ. Dev. Sustain. Doi: https:// doi.org/10.1007/s10668-018-0107-1.

DALAZOANA, K. \& MORO, R.S. 2011. Riqueza específica em áreas de campo nativo impactadas por visitação turística e pastejo no parque nacional dos campos gerais, PR. Floresta 41:387-396.

EL BIZRI, H.R., MACEDO, C.B., PAGLIA, A.P. \& MORCATTY, T.Q. 2016. Mining undermining Brazil's environment. Science. 353, 228.

FAHRIG, L. 2003. Effects of habitat fragmentation on biodiversity. Annu. Rev. Ecol. Evol. 34:487-515.

FEARNSIDE, P.M. 2016. Brazilian politics environmental policies. Science. 353:746-748.

FERRANTE, L. \& FEARNSIDE, P. M. 2018. Amazon sugarcane: A threat to the forest. Science. Doi: 10.1126/science.aat 4208 .

FERREIRA J., ARAGÃo, L.E.O.C., BARLOW, J., BARRETO, P., BERENGUER, E. BUSTAMANTE, M. GARDNER, T.A., LEES, A.C. LIMA, A., LOUZADA, J., PARDINI, R., PARRY, L., PERES, C.A. POMPEU, P. S., TABARELLI, M. \& ZUANON, J. 2014. Brazil's environmental leadership at risk. Science. 346:706-707.
FERREIRA, I.J.M., FERREIRA, J.H.D., BUENO, P.A.A., VIEIRA, L.M., BUENO, R.D.O. \& COUTO, E.V.do. 2018. Spatial dimension landscape metrics of Atlantic Forest remnants in Paraná State, Brazil. Acta Sci. Technol. 40:1-8.

FREDERICO, RM., ZUANON, J. \& DE MARCO JR, P. 2018. Amazon protected areas and its ability to protect stream-dwelling fish fauna. Biol. Conserv. 219:12-19.

GASCON, C., LOVEJOY, T.E., BIERREGAARD, R.O., MALCOLM, J.R., STOUFFER, P.C., VASCONCELOS, H.L., LAURANCE, W.F., ZIMMERMAN, B., TOCHER, M. \& BORGES, S. 1999. Matrix habitat and species richness in tropical forest remnants. Biol. Conserv. 91:223-229.

GUIMARÃES G.B., MELO, M.S. \& MOCHIUTTI, N.F. 2009. Desafios da geoconservação nos Campos Gerais do Paraná. Geologia USP - Série Publicação Especial. 5:47-61.

GUIMARÃES, G.B., ROCHA C.H., MORO, R.S. \& LICCARDO, A. 2017. Serviços geossistêmicos e a redução da APA da escarpa devoniana. IV Simpósio Brasileiro de Patrimônio Geológico, II Encontro Luso-Brasileiro de Patrimônio Geomorfológicos e Geoconservação. Ponta Grossa. p.201205.

JELIAZKOV, A., MIMET, A., CHARGÉ, R., JIGUET, F., DEVICTOR, V. \& CHIRON, F. 2016. Impacts of agricultural intensification on bird communities: New insights from a multi-level and multi-facet approach of biodiversity. Agr. Ecosyst. Environ. 216:9-22.

KAGEYAMA, P.K., GANDARA, F.B., \& SOUZA, L.M.I. 1998. Consequências genéticas da fragmentação sobre populações de espécies arbóreas. Série Técnica IPEF. 12:65-70.

LANACIÓN. 2017. Bachelet y viuda de Tompkins entregan terrenos de fundación al estado. http://www.lanacion.cl/noticias/pais/nacional/bachelet-y-viudade-tompkins-entregan-terrenos-de-fundacion-al-estado/2017-03-15/180002. html (last access in 21/03/2017).

LAURANCE, W.F. \& VASCONCELOS, H.L. 2009. Consequências ecológicas da fragmentação florestal na Amazônia. Oecol. Brasil. 13:434-451.

MAACK, R. 1948. Notas preliminares sobre clima, solos e vegetação do Estado do Paraná. Curitiba. Arq. Biol. Tecnol. 2:102-200.

MAGALHÃES, A.L.B. 2017. Brazil: Biodiversity at risk from austerity law. Nature. 542:295.

MARGULIS, C.R. \& PRESSEY, R.L. 2000. Systematic conservation planning. Nature 405:243-253.

MELO, M.S., GUIMARÃES, G.B., PONTES, H.S., MASSUQUETO, L.L., PIGURIM, I., BAGATIM, H.Q. \& GIANNINI, P.C.F. 2011. Carste em rochas não-carbonáticas: o exemplo dos arenitos da Formação Furnas, Campos Gerais do Paraná/Brasil e as implicações para a região. Rev. Espeleo-Tema. 22:81-97.

MELO, M.S., MORO, R.S. \& GUIMARÃES, G.B. 2007. Patrimônio natural dos Campos Gerais do Paraná. Ponta Grossa, Universidade Estadual de Ponta Grossa/Fundação Araucária. p.239.

METZGER, J.P., MARTENSER, A.C., DIXO, M., BERNACCI, L.C., RIBEIRO, M.C., TEIXEIRA, A.N. G. \& PARDINI, R. 2009. Time-lag in biological responses to landscape changes in a highly dynamic Atlantic forest region. Biol. Conserv. $142: 1166-1177$.

MMA - MINISTERIO DO MEIO AMBIENTE. 2017. Unidades de conservação por bioma. www.mma.gov.br/cadastro_uc (last access in 07/12/2017).

MURPHY, H.T., LOVETT-DOUST, J., 2004. Context and connectivity in plant metapopulations and landscape mosaics: Does the matrix matter? Oikos. 105:3-14.

MYERS, N., MITTERMEIER, R.A., MITTERMEIER, C.G., FONSECA G.A.B. $\&$ KENT, J. 2000. Biodiversity hotspots for conservation priorities. Nature. 403:853-858.

OLIVEIRA, E.A. 2014. Processos de criação de unidades de conservação na floresta com araucárias: o caso do Parque Nacional dos Campos Gerais, ímpar na história da política ambiental brasileira, ed. UFPR, Curitiba. 
OVERBECK, G.E, VELEZ-MARTIN, E., SCARANO, F.R., LEWINSOHN, T.M., FONSECA, C.R., MEYER, S.T., MÜLLER, S.C., CEOTTO, P., DADALT, L., DURIGAN, G., GANADE, G., GOSSNER, M.M., GUADAGNIN, D.L., LORENZEN, K., JACOBI, C.M., WEISSER, W.W. \& PILLAR, V.D. 2015. Conservation in Brazil needs to include non-forest ecosystems. Diversity Distrib. 21:1455-1460.

PARANÁ - GOVERNO DO ESTADO. 2004. Plano de manejo da área de proteção ambiental da Escarpa Devoniana. Curitiba, Paraná.

PAULITSCH, F. 2017. Diversidade de rizóbios isolados de nódulos de Mimosa gymnas Barbeby nativas dos Campos Gerais do Paraná (Brasil). Dissertação de mestrado. Universidade Estadual de Ponta Grossa - Programa de Pós-Graduação em Biologia Evolutiva.

PEREIRA, H.M., NAVARRO, L.M. \& MARTINS, I.S. 2012. Global biodiversity change: The bad, the good, and the unknown. Annu. Rev. Environ. Resour. $37: 25-50$.

PRTUR. 2014. Paraná Turismo. Paraná - Estudo estatístico 20 anos de turismo. http://www.turismo.pr.gov.br/arquivos/File/estatisticas_2012/ DadosParana2006_2011.pdf (last access in 12/07/2018)

REYNOLDS, T.W., WADDINGTON, S.R., ANDERSON, C.L., CHEW, A., TRUE, Z. \& CULLEN, A. 2015. Environmental impacts and constraints associated with the production of major food crops in Sub-Saharan Africa and South Asia. Food Secur. 7:795-822.

RIBEIRO, M.C., METZGER, J.P., MARTENSEN, A.C., PONZONI, F.J. \& HIROTA, M.M. 2009. The Brazilian Atlantic Forest: How much is left, and how is the remaining forest distributed? Implications for conservation. Biol Conserv. 142:1141-1153.

SETU. 2012. Secretaria de estado do turismo do Paraná. Dados gerais do Paraná: 2006 - 2011. http://www.turismo.pr.gov.br/arquivos/File/estatisticas_2012/ DadosParana2006_2011.pdf (last accesss in 12/07/2018)

SCHIERMEIER, Q. 2018. Europe is demolishing its dams to restore ecosystems. Nature. 557:290-291

S.O.S. MATA ATLÂNTICA. 2013. Atlas dos remanescentes florestais da mata atlântica: Relatório técnico: Período 2011-2012. São Paulo, SP.

SEAB - SECRETARIA DA AGRICULTURA E DO ABASTECIMENTO. 2015. http://www.agricultura.pr.gov.br/modules/conteudo/conteudo. php?conteudo=137 (last access in 21/09/2017).

SILVEIRA, F.A.O., FERREIRA, M.C., PERILLO, L.N., CARMO, F.F. \& NEVES, F.S. 2018. Brazil's protected areas under threat. Science. 361:459.
SOLÉ-SENAN, X.O., JUÁREZ-ESCARIO, A., ROBLEÑO, I., CONESA, J.A. \& RECASENS, J. 2017. Using the response-effect trait framework to disentangle the effects of agricultural intensification on the provision of ecosystem services by Mediterranean arable plants. Agr. Ecosyst. Environ. 247:255-264.

SOARES-FILHO, B., RAJÃO, R., MACEDO, M., CARNEIRO, A., COSTA, W., COE, M., RODRIGUES, H. \& ALENCAR, A. 2014. Cracking Brazil's Forest Code. Science. 344:363-364.

STORKEY, J., BROOKS, D., HAUGHTON, A., HAWES, C., SMITH, B.M. \& HOLLAND, J.M. 2013. Using functional traits to quantify the value of plant communities to invertebrate ecosystem service providers in arable landscapes. J. Ecol. 101:38-46.

THOMAS, P. 2013. Araucaria angustifolia. The IUCN Red List of Threatened Species http://dx.doi.org/10.2305/IUCN.UK.20131.RLTS T32975A2829141.en (last access in 25/09/2017).

TILMAN, D., CLARK, M., WILLIAMS, D.R., KIMMEL, K., POLASKY, S. \& PACKER, C. 2017. Future threats to biodiversity and pathways to their prevention. Nature. 546:73-81.

TÓFOLI, R.M., ALVES, G.H.Z., DIAS, R.M. \& GOMES, L.C. 2016. Brazil's Amazonian fish at risk by decree. Science. 353:229-229.

TÓFOLI, R.M., DIAS, R.M., ALVES, G.H.Z., HOEINGHAUS, D.J., GOMES, L.C., BAUMGARTNER, M.T. \& AGOSTINHO. A.A. 2017. Gold at what cost? Another megaproject threatens biodiversity in the Amazon. Persp. Ecol. Conserv. 15:129-131.

TOLLEFSON, J, 2016. Brazil debates loosening environmental protections. Nature. 539:147-148.

TSCHARNTKE, T., TYLIANAKIS, J.M., RAND, T.A., DIDHAM, R.K., FAHRIG, L., BATÁRY, P., BENGTSSON, J., CLOUGH, Y., CRIST, T.O., DORMANN, C.F., EWERS, R.M., FRÜND, J., HOLT, R.D., HOLZSCHUH, A., KLEIN, A.M., KLEIJN, D., KREMEN, C., LANDIS, D.A., LAURANCE, W., LINDENMAYER, D., SCHERBER, C., SODHI, N., STEFFAN-DEWENTER, I., THIES, C., VAN DER PUTTEN, W.H. \& WESTPHAL, C. 2012. Landscape moderation of biodiversity patterns and processes - eight hypotheses. Biol. Rev. 87:661-685.

VIEIRA, R.R.S., RIBEIRO, B.R., RESENDE, F.M., BRUM, F.T., MACHADO, N., SALES L.P., MACEDO, L., SOARES-FILHO, B., \& LOYOLA, R. 2018. Compliance to Brazil's Forest Code will not protect biodiversity and ecosystem services. Divers. Distrib. 24:434-438. 